\title{
Czene-Polgár Viktória: Adópolitika a Rákosi-kor első éveiben
}

\begin{abstract}
Absztrakt
A második világháborút követő idöszakban a háborús pusztítás, az ennek következtében parlagon maradó szántóföldek, az ipari üzemek pusztulása, a termelés leállása, a megszálló szovjet hadsereg ellátása, a jóvátételi kötelezettségek, valamint a világ eddig ismert legnagyobb mértékü inflációja mind-mind óriási terhet jelentett az ország számára, romba döntve annak gazdaságát. Az állami költségvetés bevételei a kiadások alig tizedét fedezték. A helyzet megoldásához gyors és radikális intézkedésekre volt szükség, azonban az állami beavatkozás módjának és mértékének tekintetében a politikai pártok álláspontjai eltéröek voltak. A hatalmat 1945 után megszerzö Magyar Kommunista Párt adópolitikája alapvetöen a tulajdonviszonyok megváltoztatásának, a társadalmi szerkezet erőszakos átalakitásának célját szolgálta, annak eszközévé vált. Kulcsszavak: koalíciós idöszak, Rákosi-kor, gazdaságpolitika, adópolitika, diktatúra
\end{abstract}

\begin{abstract}
The devastation of World War II and its consequentces, i.e. the land that was left fallow, the destruction of industrial factories, the breakdown of production, the mandatory supply of the occupying Soviet army, the reparation obligations and the highest inflation rate known to date, all together put an enormous burden on Hungary, that eventually crashed its economy. At the time the state revenue covered only onetenth of the expenditure, therefore rapid and radical measures were needed to resolve this situation, but the positions of the political parties differed greatly in the nature and extent of state intervention. The aim of tax policy of the Hungarian Communist Party that gained power after 1945, was essentially to replace private property with public ownership what mainly served as a tool for violently transforming the social structure. Keywords: coalition period, Rakosi era, economic policies, tax policy, dictatorship
\end{abstract}

$* * *$

\section{Bevezető}

„Az új adópolitika célja: minél gyorsabban minél nagyobb adóbevételeket biztositani az állam számára." - hirdette a Magyar Kommunista Párt központi lapja 1945. december 18-án a II. világháborút követő válságból való kilábalás egyetlen elfogadhatónak tartott útját. ${ }^{117}$

Kétségtelen, hogy állami bevételekre minden addiginál nagyobb szükség volt. Ugyanis az 1944-45-ös hadiesemények miatt az állam nyolc hónapig alig rendelkezett pénzbevétellel. Elpusztult a nemzeti jövedelem forrásainak jelentős része; az ipar kapacitásának mintegy 90 százaléka rongálódott vagy megsemmisült, a közlekedési eszközök a visszavonuló német vagy az elöretörő szovjet csapatok zsákmányává váltak. Ráadásul az 1945. évi aratás sikertelen volt: az 1938. évi kenyérgabona termésének

${ }^{117}$ Szabad Nép, III. évfolyam, 218. szám, 1945. december 18. Forrás: wwww.arcanum.hu 
mindössze csak a harmadát sikerült betakarítani, aminek a jelentős részét vetőmagra kellett félretenni. Az 1945-46-os gazdasági évben (akkor a költségvetési év még júliustól júniusig tartott) a megtermelt nemzeti jövedelem az utolsó békeév (1938) nemzeti jövedelmének mintegy egyharmadát tette csak ki. ${ }^{118}$

Mindezeken felül az országot 300 millió dolláros jóvátételi kötelezettség sújtotta, ${ }^{119}$ és további jelentős terhet jelentett a megszálló Szovjet Vörös Hadsereg és a Szövetséges Ellenőrző Bizottság ellátása élelemmel, közlekedési eszközzel, üzemanyaggal. ${ }^{120}$ Ugyan a szovjet külügyminiszter-helyettes, A. J. Visinszkij ${ }^{121}$ szerint „a Magyarország által teljesítendő jóvátételi kötelezettségek és a megszálló csapatok jelenléte Magyarországon nem gyakorol, és nem gyakorolhat semmiféle komoly hatást az országban uralkodó gazdasági helyzetre", ${ }^{122}$ valójában a nemzetközi kötelezettségek a háború utáni pár évben felemésztették a költségvetési kiadások közel 40 százalékát. ${ }^{123}$

A helyzetet a növekvő mértékü infláció is nehezítette. A folyamat már az 1930as években elkezdődött: 1938-ban a kormány meghirdette a fegyverkezés gyorsítását célzó Győri programot, amely öt év alatt egy milliárd pengő beruházást irányzott elő hadi célokra. Az összeg nagyságát mutatja, hogy a harmincas években az egész magyar gazdaság tőkefelhalmozása évente nem haladta meg a 180 millió pengőt. Ebben a helyzetben kívántak tisztán állami eszközökből évi 200 millió pengőt beruházni. Éppen ezért 1938-ban módosították a jegybanktörvényt, lehetővé téve, hogy a jegybank fedezetlen hitelt bocsásson a kormány rendelkezésére. A bankjegyforgalmat tovább növelték a Németországnak ellenszolgáltatás nélkül teljesített export és más szolgáltatások. 1942. december 21-én Magyarország márkakövetelése 540 millió volt, 1943 decemberében ez az összeg 978 millió márkára nőtt, az 1944. március 19-én történt német megszállást követően keletkezett német adósság pedig 2918 millió pengő tett ki, ami a bankjegyforgalom ugyanerre az időre eső szaporulatának körülbelül a 40 százaléka volt. ${ }^{124}$ „Az így felhalmozódó, fedezetlen jegybankpénz, továbbá a háború miatt felduzzadó költségvetési hiány, párhuzamosan a lecsökkent árualappal és a mindezek hatására felerősödő spekulációval a világban addig még nem tapasztalt inflációs hatásokat váltott ki." 125

A hitelpiac gyakorlatilag megszűnt, a bankok a túlélésükért küzdöttek, így valós hitelezési tevékenységet sem tudtak folytatni. Források és exportlehetöségek hiányában

\footnotetext{
${ }^{118}$ SCHLETT András: A magyar tanulópénz - Hiperinfláció és stabilizációMagyarországon 1945-46-ban. (kézirat) é.n. p. 2.

${ }^{119}$ BARNA Attila - HORVÁTH Attila - MÁTHÉ Gábor - TÓTH Zoltán József: Magyar Állam- és jogtörténet. Budapest, Nemzeti Közszolgálati Egyetem, 2014. forrás: http://m.ludita.uninke.hu/repozitorium/bitstream/handle/11410/9983/Teljes\%20sz\%C3\%B6veg!?sequence=1\&isAllowed=y (Letöltve: 2019. 01.22.) pp. 323-326.

${ }^{120}$ HorvátH Julianna - SzABÓ Éva - SzÜCS László - ZALAI Katalin (szerk.): Pártközi értekezletek... Politikai érdekegyeztetés, politikai konfrontáció 1944-1948. Budapest, Napvilág Kiadó, 2003. p. 38.

${ }^{121}$ Andrej Januarjevics Visinszkij (1883-1954) lengyel származású szovjet jogász, 1935-től a Szovjetunió föügyésze, s ezen posztján a sztálini tisztogatások egyik fö levezénylője. 1940-49 között külügyi népbiztos- illetve külügyminiszter-helyettes, 1950-53 között külügyminiszter.

${ }^{122} \mathrm{G}$. VASS István: Tildy Zoltán kormányának minisztertanácsi jegyzökönyvei 1945. november 15.-1946. február 4. Magyar Országos Levéltár kiadványai, II. Forráskiadványok 41. Budapest, 2005. p. 31.

${ }^{123}$ HonváRI János: Magyar jóvátétel a II. világháború után. In: RubicOnline 2012/3. www.rubiconline.hu (Letöltve: 2019.04.17.)

${ }^{124}$ SCHLETT i. m. p. 129.

125 LENTNER Csaba: A magyar állampénzügyek fejlödéstörténete a dualizmus korától napjainkig. L'Harmattan, Budapest, 2019. pp. 78-79.
} 
érdemi importról nem lehetett szó, az Ideiglenes Nemzeti Kormány ${ }^{126}$ nem jutott bevételekhez. Azonban az állam külföldi adóssága, a külföldi valutában és pengőben fizetendő tartozások összege egyre nőtt: az állami költségvetés kiadásainak összege tízszerese volt a bevételeknek. Emiatt a Nemzeti Bank - kormányutasításra - fedezetlen kölcsönökkel pótolta a költségvetési hiányt.

Mindeközben páratlan méretü versenyfutás kezdődött az árak és a bérek között. 1945 júliusában még napi egy százalék volt az átlagos áremelkedés, októberben 18; 1946 májusától elszabadult a pokol, a napi 1012 százalékos áremelkedéssel, ami július első hetében 45 900, második hetében 53 ezer százalékra ment. Július negyedik hetében 158486 százalékos áremelkedést mutatott a napi index. Az utcákat papírtenger borította. ${ }^{127} 1946$ nyarára a pengő elértéktelenedése már annyira felgyorsult, hogy naponta fizették a munkabért, amelyet mindenki igyekezett azonnal adópengőbe, dollárba fektetni, illetve levásárolni, mert másnap már új, még magasabb címletủ pénz került a forgalomba. Mind nagyobb méreteket öltött a közvetlen árucsere, s ennek formája a batyuzás. A munkabér pénzbeli része csaknem névlegessé vált, bevezették a természetbeni bért.

Az inflációs folyamatról azt tartották, hogy az ,a legkeservesebb adóteher es a legzsarnokibb kényszer megtakarítás. Az életmód leszállításából és inflációs adókból, szóval a tömegek szája elől elvont falatokból állították helyre a hidakat, vasutakat, fedtek be a házakat, gyárakat és mühelyeket. Az adózók infláció nélkül sohasem lettek volna hajlandók és képesek az óriási befektetési, helyreállítási szükségletek fedezésére szükséges áldozatokat adóemelés formájában magukra vállalni. Tán éppen ez az inflációs közgazdaságnak a mélyebb értelme es tán vigasza is, ha bármilyen tragikus is" "28 1945-öt követően azonban az adózókat nemcsak az infláció, hanem sokkal inkább az egyre szigorodó állami büntetőpolitika hajtotta abba az irányba, hogy a „szükséges áldozatokat adóemelés formájában" magukra vállalják.

Már 1945-ben történtek próbálkozások az inflációs folyamat megfékezésére: december 19-én bevezették a lebélyegzés módszerét alkalmazó bankjegydézsmát. ${ }^{129} \mathrm{Az}$ állam pedig - a jelentős pénzkivonásból származó haszon mellett - a bélyegekből is bevételre tett szert, így úgy tűnt, fellélegezhet. A megkönnyebbülés átmeneti volt -11 napig tartott. ${ }^{130}$ Hiszen a béreket nem igazították ki a módszernek megfelelően, így a jövedelmek magasabbak lettek, mint amekkora árufedezet a rendelkezésre állt. Emiatt emelni kellett az árakat, amely lépés magával hozta az újbóli béremelési követeléseket. Az így kialakult bér-ár spirál tovább fokozta az inflációt, és számos visszaélésre is módot adott.

1946. január 1-jén bevezették az adópengőt, amely eredetileg mintegy elszámolási egységként, a közadók, közüzemi díjak és egyéb szolgáltatások adópengőben kivetett ellenértékének lerovására szolgált -, ${ }^{131}$ gyakorlatilag pénzként

\footnotetext{
${ }^{126} \mathrm{Az}$ Ideiglenes Nemzetgyülés felállítását követően, 1944. december 22.-én Debrecenben megalakult és 1945. november 15.-ig müködő, Dálnoki Miklós Béla vezérezredes által vezetett kormány.

${ }^{127}$ SCHLETT i. m. p. 2.

${ }^{128}$ VÁGÓ József: Infláció - stabilizáció. Magyar Gazdasági Évkönyv 1945-1947. Budapest, 1947. p. 112.; valamint HuszTi Ernő: Hetven éves a magyar forint. Pénzügyi Szemle 2016/4. p. 448.

${ }^{129}$ Eszerint ha valakinek volt négy darab, egyenként ezer pengő névértékű bankjegye, háromért bélyeget kellett vennie, amit a negyedikre ragaszthatott; így négyezerből ezer pengője maradt.

${ }^{130}$ VARGA István: Az újabb magyar pénztörténet és egyes elméleti tanulságai. Közgazdasági és Jogi Könyvkiadó, Bp., 1964. pp. 103-104.

${ }^{131}$ Az 5970/1946. M.E.számú rendelet értelmében az adópengővel az adók mellett egyes közüzemi díjak, szolgáltatások és bizonyos termékek is kifizethetőek voltak.
} 
funkcionált. ${ }^{132}$ Értékét a pengőhöz viszonyítva állapították meg. ${ }^{133}$ Az aktuális arányszámot a Pénzügyminisztérium a Magyar Közlöny 1946. január 5-én megjelenő számában tette közzé, ${ }^{134}$ innentől a Magyar Gazdaságkutató Intézet az indexszámot naponta megjelentette. Például 1946. március 1 -jén 1 adópengő 10 , június 1 -jén 160.000, július 1-jén 7.500.000.000 pengőt ért. ${ }^{135}$ Június 24 -től mind a magán-, mind az állami vállalatok számára kötelezővé tették a bérek adópengőben - ráadásul kéthetente - történő kifizetését, de Beszkárt és HÉV jegyeket is lehetett adópengőért vásárolni. ${ }^{136}$ Ezen a ponton a Nemzeti Bank vezetősége is tiltakozott, arra hivatkozva, hogy az adójegyek a fizetőeszköz szerepét betöltve sértik a jegybanknak a bankjegyek kibocsátására vonatkozó kizárólagos jogát. Mindezek ellenére a Pénzügyminisztérium július 8-án rendeletben tette törvényes fizetőeszközzé a pengő helyett az adópengőt. ${ }^{137}$ A készpénzfogalomba való kerülés egyben az adópengő végét is jelentette: július végére teljesen elértéktelenedett. „1946 júliusának második felében a forgalomban lévő bankjegyek összértéke már csupán kb. 600.000 dollárnak felelt meg. ",138

\section{Az adópolitikai irányok meghatározása a háborút követő hónapokban}

Az egyik oldalon tehát sorakoztak azok a tényezők, mint a háború okozta pusztítás, a jóvátételi kötelezettség, a közellátási zavarok, az infláció, a létfenntartást veszélyeztető elszegényedés, ${ }^{139}$ a másik oldalon pedig az ország újjáépítésének (a közlekedés mielöbbi megindításának, a vasutak, hidak újjáépítésének), valamint a közigazgatási apparátus helyreállításának kényszere, amelyhez gyakorlatilag üres állampénztár társult, hiszen a kötelezettségekhez képest az állami bevételek 1945 szeptemberében a költségek csupán $9 \%$-át fedezték. ${ }^{140}$

${ }^{132} \mathrm{Az}$ adópengő - majd a nem sokkal később bevezetett adójegy -nem határozható meg pénzként, bankjegyként; nem is a Magyar Nemzeti Bank hozta forgalomba, hanem a Pénzügyminisztérium.

${ }^{133}$ Egy adópengő - a bevezetésekor - egy pengő értéknek felelt meg. Az ,árfolyamot”a Varga István közgazdász által 1928-ban alapított Magyar Gazdaságkutató Intézet határozta meg, értékét a kiskereskedelmi árindexhez kötötték. Varga István Feljegyzések az adópengő árfolyamának alakulásához címủ írásából kiderül, hogy az árindex összetételét „,50\%-os mérlegelési súllyal szereplő mezőgazdasági (élelmezési) rész, 20\%-os súllyal szereplö, kötött árakon számított iparcikk hányad és 30\%-os súllyal szereplö, szabadpiaci árakon számított iparcikk hányad” adta. In: MAJOROS Krisztina: A múlt század jeles magyar közgazdásza: Varga István. MTA Közgazdaságtudományi Kutatóközpont, Budapest, 2003. http://docplayer.hu/9010881-A-mult-szazad-jeles-magyar-kozgazdasza-varga-istvan-1897-1962.html (Letöltve: 2019.02.16.) p. 30.

134 77.022/1946. PM sz. hirdetmény

${ }^{135}$ MARTON Ádám: Infláció, fogyasztói árak Magyarországon a II. világháború után (1945-1968). In: Statisztikai Szemle 90. évfolyam, 5. szám, 2012. május. 376.0. http://www.ksh.hu/statszemle_archive/2012/2012_05/2012_05_001.pdf (Letöltve: 2019. 01.23.) p. 376.

${ }^{135}$ HONVÁRI János (szerk.): Magyarország gazdaságtörténete a honfoglalástól a 20. század közepéig. Aula, Budapest, 1997. p. 376.

${ }^{136}$ DANYI Pál: Hiperinfláció 4. rész: 1946. május végén jelent meg az adópengő mint papírpénz. 2016. Forrás:

http://webcache.googleusercontent.com/search?q=cache:VERCa1nUc9MJ:https://www.artortenet.hu/inde x.php/item/124-hiperinflacio-4-resz-1946-majus-vegen-jelent-meg-az-adopengo-mint-

papirpenz\&client=firefox-b\&hl=hu\&gl=hu\&strip=1\&vwsrc=0 (Letöltve: 2018 . december 17.)

137 2240/1946. PM-rendelet

${ }^{138}$ TOMKA Béla: A magyarországi pénzintézetek rövid története 1936-1947. Budapest, Aula Kiadó, 2000. p. 133.

${ }^{139}$ PETŐ Iván - SzAKÁCS Sándor: A hazai gazdaság négy évtizedének története 1945-1985. I. Az újjáépítés és a tervutasitásos irányítás idöszaka. Budapest, Közgazdasági és Jogi Könyvkiadó, 1985. p. 51.

${ }^{140}$ MóD Aladár: Az újjáépités gazdaságpolitikája. In: Társadalmi Szemle I. évfolyam, 1. szám, 1946. p. 14. 
A kialakult válsághelyzet kezelése gyors és radikális intézkedéseket követelt. A kérdést a törvényhozásban is folyamatosan napirenden tartották, $\mathrm{s}$ abban általában konszenzus volt, hogy a termelés és a hitelellátás terén egyaránt állami beavatkozásra van szükség. Ám annak módja és mértéke tekintetében mát ütköztek az álláspontok. Ráadásul a döntések valójában nem ezen a fórumon és a legkevésbé sem önállóan születtek: a gazdaságpolitika kialakítása erősen nélkülözte az önállóság jegyeit. ${ }^{141}$ Magyarország számára a politikai, gazdasági kereteket a szovjetek jelölték ki, akik a világhatalmi pozíció megszerzéséhez vezető utat, mint legfőbb célt, a megszállt államokban történő tartós berendezkedésben, a „befolyási övezet” kialakításában látták. Ezekre a területekre pedig változtatás nélkül kívánták adaptálni saját ideológiai, politikai és gazdasági módszereiket. ${ }^{142}$ Elképzeléseikbe pedig nem fért bele az államháztartási egyensúly helyreállításának egyik legkézenfekvőbb eszköze, a hitelfelvétel. Ezen elképzelést a polgári pártok támogatták, azonban a kommunista párt hallani sem akart arról, hogy Magyarország nyugati segítségért folyamodjon, ami ellentétben állt a szovjetek akaratával. Az államháztartási hiányt ezért 1945 végétől adókkal igyekeztek pótolni, emellett emelték a munkaadói és a szociális terheket. ${ }^{143}$

A háborút követően sorra jelentek meg a különböző adónemeket szabályozó rendeletek. ${ }^{144}$ Ugyan az adópolitikai elképzelések megvalósításához elvileg még a koalíciós partnerek támogatására is szükség volt, hiszen az Ideiglenes Nemzeti Kormányban a pénzügyminiszteri poszt a kisgazdáké lett, s a kommunisták csak a politikai államtitkárt jelölhették, de a kommunista párt képviselöi rövidesen a gazdaságirányítás területén (is) megtalálták a hatásköri viták elrendezésének sajátos lehetőségét, amikor is „az országot fenyegető gazdasági katasztrófa elhárításának érdekében" egy teljhatalommal rendelkező kormányzati szerv megalakítását szorgalmazták, amely az egyes gazdasági szakminiszterekre és egyéb állami szervekre összefogóan rendelkezéseket hozhat. ${ }^{145}$ Révai József az 1945. november 4-én tartott pártközi értekezleten egy gazdasági direktórium létesítését javasolta, ${ }^{146}$ tíz nappal később pedig megállapodás jött létre arról, hogy a ,gazdasági kérdések egységes irányítására", a miniszterelnök, a kereskedelemügyi és az iparügyi miniszter részvételével, Gazdasági Főtanácsot állítanak fel. ${ }^{147} \mathrm{~A}$ november 21-én tartott kormányülésen Tildy Zoltán be is jelentette, hogy három nappal későbbre összehívta a

141 „Míg 1938-ban a Magyar Gazdaságkutató Intézet akkori számításai alapján a vállalatok szociális jellegü kiadásai nem érték el a kifizetett munkabér 10 százalékát (számításaik szerint 9,7\%-ot), addig az Intézet 1946/47-re végzett kalkulációja azt mutatta, hogy ezek a kiadások a kifizetett munkabérnek megközelítették az ötven százalékát.” BEREND T. Iván: A gazdaságpolitika fö vonásai Magyarországon (1948-1968). Hosszú távú Tervezés Közgazdasági Bizottsága által megvitatott tanulmány. 2009.04.23. http://www.makrotrend2000.hu/index.php?id_embed=13. (Letöltve: 2019.0127.$)$ p. 9.

${ }^{142}$ A kérdésről lásd bővebben: BARÁTH Magdolna: A Kreml árnyékában. Tanulmányok Magyarország és a Szovjetunió kapcsolatainak történetéhez, 1944-1990. Gondolat Kiadó, Budapest, 2014. 21-40. pp.

${ }^{143}$ MAJOROS i. m. 2003. p. 40.

${ }^{144} 1945$. május 22-én például bevezették a városi általános forgalmi adót, amely 5 százalékos adót vetett ki minden, a föváros területén folytatott állandó vagy alkalmi önálló kereskedelmi, ipari vagy egyéb (de nem szolgálati és munkabérviszonyból eredő) kereseti tevékenységből származó bevételre, függetlenül attól, hogy a tevékenységet üzletben, lakásban, vagy akár telephely nélkül gyakorolták. Az adó összegét a kerületi elöljáróságokon beszerezhető „,városi általános forgalmiadó” bélyegjegyekben naponta kellett befizetni, vagy számolólappalkellett leróni.

${ }^{145}$ CSIZMADIA Tamás: A hatalomátvétel - Út a kommunista totális állam felé 1944 december 21-töl a jogági szilárdulásig. Doktori értekezés. 2016. https://ajk.pte.hu/files/file/.../csizmadia-tamas/csizmadiatamas-muhelyvita-ertekezes.pdf (Letöltve: 2019.01 29.) p. 108.

146 1946. január 29.-i ülés. G. VASS i. m. 2005.

${ }^{147}$ Szabadság I. évfolyam, 247. sz., 1945. november 16. 
Gazdasági Főtanács (GF) első ülését. ${ }^{148}$ A szervezetet életre hívásáról szóló jogszabályok 1946. január 9-ig várattak magukra. Ekkor jelent meg a Magyar Közlönyben két rendelet, az egyik a Gazdasági Főtanács létesítéséről és müködéséről, ${ }^{149}$ a másik tételesen felsorolta azokat az ügyköröket, amelyekkel kapcsolatban rendelet kibocsátására jogosult, akár önállóan, akár a szakminiszterrel egyeztetve. ${ }^{150}$ A GF hatásköre - rendeletekkel alátámasztottan és bővítetten - ${ }^{151}$ kiterjedt a gazdasági élet, ezen belül a pénz- és anyaggazdálkodás, az ár- és bérszabályozás, a hitelélet, a közellátás és az adópolitika területeire. Mivel a koalíciós struktúrából nem következett automatikusan a kommunista párt központi, befolyásoló szerepe, ezért a GF végrehajtó szervét, a Titkárságot szerezték meg, amelyet a GF négy éves müködése alatt mindvégig a kommunista Vas Zoltán irányított fơtitkárként - államtitkári címmel és ranggal -, s ebbéli szerepkörében gyakorlatilag a testület legföbb döntéshozója lett. A Titkárság székhelye a Pesti Magyar Kereskedelmi Bank központjának első emeletén, az V. kerületi József Attila utca 2-4. szám alatti épületben került elhelyezésre, ahol korábban a miniszterelnökség székelt, s ahová 1953-ban az Államvédelmi Hatóság több részlegét helyezték.

Tehát „,a gazdaságirányítás gyakorlatilag kikerült a kormány hatásköréből és ténylegesen a kommunista párt kezébe ment át." ${ }^{152}$ Amint azt Sulyok Dezső, kisgazda politikus megfogalmazta: „Ha a kormánnyal szemben van egy olyan szerv, amely a kormány mellett, vagy esetleg a kormány felett áll, s amelynek szervi összetétele más, mint a kormányé, és amely rajta tartja kezét a gazdasági élet pulzusán - ellenjegyzése nélkül kiutalások a Nemzeti Bankból nem történhetnek -, akkor végeredményben a kormány kezéből ki van véve a gazdasági hatalom."153

\footnotetext{
${ }^{148}$ A Gazdasági Főtanács megalakulásáról, kezdeti működéséről ld. bővebben: GERMUSKA Pál: Adalékok a magyarországi gazdasági intézményrendszer 1945-1948 közötti változásaihoz. In: Lépések a gazdasági teljhatalom felé 1945-1948. Nemzeti Emlékezet Bizottsága, Budapest, 2017. pp. 35-42.; valamint GYARMATI György: A Rákosi-korszak. Rendszerváltó fordulatok évtizede Magyarországon, 1945-1956. ÁBTL-Rubicon, Budapest, 2011. p. 67.

149 12.090/1945. M.E. sz. rendelet. Ennek alapján a GF javaslatokat tehetett a minisztertanácsnak, véleményt nyilvánított egyes miniszteri indítványokról, gazdasági vonatkozású rendeletek kiadását kezdeményezte, illetve maga is rendeleteket bocsáthatott ki, amelyet a miniszterelnök, mint a GF elnöke írt alá. A GF első elnöke Tildy Zoltán lett, a tagjai pedig Bán Antal iparügyi és Gerő Ernő közlekedésügyi miniszter voltak, majd 1946. február 14-én csatlakozott a tagok közé Bárányos Károly közellátásügyi és Gordon Ferenc pénzügyminiszter.

150 230/1946 M.E. sz. rendelet. Eszerint a GF jogosult volt többek között az ásványi anyagok kitermelését és a villamosenergia-termelést érintő kérdések szabályozására, e termékek forgalmának ellenőrzésére; a gazdasági feladatokat ellátó állami és önkormányzati szervek, valamint magánszervezetek gazdasági müködésének ellenőrzésére, szükség esetén átszervezésére; valamennyi munkavállaló járandóságainak megváltoztatására, esetleg rendkívüli járandóság megállapítására; volt az áruk kivitelét és behozatalát, az ország gazdasági helyzetének alakulását, a külföldi fizetési eszközök forgalmát, esetleg beszolgáltatását érintő intézkedések megtételére; a mezőgazdasági termények termelésének és más termékek előállításának fokozását, illetve forgalmának szabályozását célzó intézkedések megtételére; a munkaerőgazdálkodás irányítására és ellenőrzésére; a termelő üzemek működése közötti összhang megteremtését célzó intézkedések megtételére; és a közellátást, valamint egyes közszükségleti cikkek forgalmát érintő intézkedések megtételére. Idézi: G. VASS i. m. 2005. p. 45.

${ }^{151}$ Az intézmény jogkörét a 3650/1946. M.E. sz. rendelet, majd a 8530/1947. Korm. rendelet bővítette, ez utóbbi beemelte a GF-be az Országos Tervhivatal elnökét, alelnökét és főtitkárát

${ }^{152}$ IzSÁK Lajos: Rendszerváltástól rendszerváltásig. Magyarország története 1944-1990. Kulturtrade Kiadó, Budapest, 1998. p. 57.

${ }^{153}$ Nemzetgyülési Napló, 1946. február 8. 397.o. Forrás: www.arcanum.hu
} 
Az MKP 1945 novemberében ismertetette gazdasági programját, ${ }^{154}$ amelyben a szintén a szovjet mintát követő - adópolitikai nézeteiket is kifejtették. ${ }^{155} \mathrm{~A}$ program egyik alapvetése szerint az állami kiadások fedezetéül szolgáló forrásokat a lakosság tehetősebb rétegétől kellett elvonni. Ennek megfelelően javasolták a kereskedők, iparosok, vállalkozók, gyárosok már meglévő adójának progresszív alapú megemelését, továbbá egyszeri vagyonszaporulat alapján vagyonváltság kivetését, valamint ugyanezen réteg számára olyan új adónemek bevezetését mint pl. az üzlethelyiség adó, fényüzési adó. ${ }^{156}$ Már 1945 végén új adórendszabályok bevezetését határozták el: decemberben a minisztertanács elé került három tervezet, amelyek rövidesen rendeleti formát öltöttek: úgymint a közadók kezeléséröl szóló egyes rendelkezések módosítása és kiegészitése tárgyában hozott a 11 610/1945. M.E. sz. rendelet, a szolgálati és munkabérviszonyból származó jövedelmek adóztatásáról szóló 11 620/1945. M.E. sz. rendelet és a közadóknak adópengöben való meghatározásáról szóló 11 600/1945. M E. sz. rendelet. ${ }^{157}$ Ezeken túl a házadót felváltotta a lakásadó, amely a lakásokon túl adókötelezettség alá vont minden más helyiséget is (üzletet, elárusító bódét, irodát, rendelőt, mütermet, mühelyt, raktárt, gyárat, stb.), és összegét nem a tulajdon, hanem a használat, illetve a bérlet alapján szabták ki, s ennek során nem volt mérvadó az, hogy a lakásadó alá eső helyiség a házadó alól állandó vagy ideiglenes mentességben részesülte. ${ }^{158} \mathrm{Az}$ adó mértékét jól tükrözi a Polgári Demokrata Párt napilapja, a Világ 1945. december 30-iki száma, amelynek szalagcíme a következő volt: „Itt a lakásadó: a házbér kétszáz- és ötszázszorosa. "159

A mezőgazdaságból élők alapvetően két jogcímen járultak hozzá az államháztartási bevételekhez: egyrészt az elért jövedelmeik után adót fizettek, másrészt a megtermelt termékeik egy részét kötelező beadás formájában, a termékek értékénél alacsonyabb áron kellett az állam rendelkezésére bocsátaniuk, míg az eltitkolt felesleget ellenszolgáltatás nélkül elkobozták. ${ }^{160} \mathrm{Az} 1945$ utáni beszolgáltatások során az állam, közellátási érdekekre hivatkozva a paraszti gazdálkodásokba avatkozott be, gyakorlatilag a parasztság emelt szintű adóztatását valósították meg. ${ }^{161}$ A begyüjtések

\footnotetext{
154 „Javaslatok az országot fenyegető gazdasági katasztrófa elhárítására” - 1945. november 22. Idézi: G. VASS i. m. 2005. p. 35., 41.

${ }^{155}$ A szovjetek legfőbb adópolitikai alapvetése az volt, hogy az állam kiadásainak fedezése elsősorban az állami vállalatok és a gazdasági szervezetek feladata: a költségvetési bevétel legnagyobb hányadát a forgalmi adóknak valamint az állami vállalatok és szervezetek nyereségrészesedéseinek kell kitennie. Ezt követik a lakosság közvetlen és közvetett adózásai, amelyek kivetése viszont a „szocialista igazságosság” jegyében zajlik, vagyis a rendszer a városi és falusi munkásokat premizálja a jómódú társadalmi rétegek, a magánvállalkozók, kereskedők, kulákok rovására, mintegy büntető jelleggel. A témában a korszakban több szovjet szerző tanulmánya is megjelent, pl. D. PETROVszKIJ: A népi demokrácia országainak gazdasági föllendülése. In: Magyar-Szovjet Közgazdasági Szemle, III. évfolyam 1-6. szám, 1949. januárjúnius. p. 185.; V. DJACSENKO: A szovjet pénzügyi rendszer jellegzetességei és előnyei. In: MagyarSzovjet Közgazdasági Szemle, Magyar-Szovjet Közgazdasági Szemle, III. évfolyam 1-6. szám, 1949. január-június pp. 397-416.

${ }^{156}$ G. VASS i. m. 2005. p. 36.

${ }^{157}$ Magyarországi rendeletek tára, 1945. Szikra Irodalmi és Lapkiadó Vállalat, Budapest, 1946. forrás: https://library.hungaricana.hu/hu/view/OGYK RT 1945/?pg=0\&layout=s (letöltve: 2019.07.03)

${ }^{158} 12.410 / 1945$. M. E. számú rendelete a lakásadó tárgyában. Magyar Közlöny, 1946.01.01/1. szám

159 Világ, 1945. december 30. (185. szám)

${ }^{160}$ GöNCZÖL József - LÁBÁN József: A mezögazdasági jövedelemadó új rendszere. In: Közgazdasági Szemle, III. évfolyam, 1956.

161 A beszolgáltatott mennyiség volt az alapja a városi lakosság jegyrendszer keretében történő ellátásának, a Szövetséges Ellenőrző Bizottság szükségletei biztosításának, illetve a hadisarcként átadandó terményeknek.
} 
során eleinte az 1942-ben kidolgozott, ún. Jurcsek-rendszerben ${ }^{162}$ foglaltak szerint jártak el, majd április 20-án megjelent a közellátásügyi miniszter 1945. évi 11.850. számú rendelete, az egyes mezögazdasági termények beszolgáltatásáról, forgalmáról és felhasználásáról, amely a korábbiaknál is szigorúbb rendelkezéseket tartalmazott. Nem a beszolgáltatandó termény mennyiségét határozták meg, hanem azt, hogy egy bizonyos terményből a háztartásmennyit tarthat meg, ${ }^{163}$ az e fölötti mennyiséget pedig kötelezően be kellett szolgáltatni. ${ }^{164}$ A kötelező terménybeszolgáltatás megtörténtét a községi elöljáróság - a polgármester - ellenőrizte, de az eljárásban való közremüködésre a helyi Nemzeti Bizottságokat is fel lehetett kérni.

A rendeletben felsorolt termények megvásárlásának és felhasználásának irányítását, forgalmának ellenőrzését, a megvásárolt készletek nyilvántartását, valamint a vásárlásra jogosított kereskedők tevékenységének ellenőrzését az áruforgalmi hivatalok (terményhivatalok) látták el. ${ }^{165} \mathrm{Az}$ adóbevételek közé tartozott továbbá az 1945 júliusában bevezetett, természetben fizetendő földadó, ${ }^{166}$ amelynek mértéke aranykoronánként $1 \mathrm{~kg}$ búza volt. ${ }^{167} \mathrm{Ez}$ olyan mértékű megterhelést jelentett a beszolgáltatási kötelezettségeket is teljesíteni kényszerített parasztok számára, hogy pénzügyminisztérium 1946 februárjában javaslatot tett arra, hogy az adót a 600 négyszögölnél nem nagyobb területtel rendelkező földtulajdonosok pénzben róhassák le. ${ }^{168}$ A földadó később beépült a beszolgáltatási kötelezettségekbe.

Összességében, a kommunista adópolitikáról tehát már a háborút követő hónapokban elmondható volt, hogy az - úgy a tervezés, mint a megvalósítás tekintetében -, alapvetően a tulajdonviszonyok megváltoztatásának, a társadalmi szerkezet erőszakos átalakításának célját szolgálta, annak eszközévé vált.

162 Jurcsek Béla (1893-1945); 1942.július 14. - 1944. március 22. között a Közellátási Hivatal államtitkára volt, majd október 16-ig földmüvelésügyi és közellátási tárca nélküli miniszter, végül közellátásügyi miniszter lett. 1942-ben dolgozta ki a mezőgazdasági termények és termékek új beszolgáltatási rendszerét, a növekvő háborús szükségletek kielégítésére. E szerint a beszolgáltatási kötelezettséget a szántóterület kataszteri tiszta jövedelme alapján szabták meg. Minden aranykorona után 50 búzaegységet ( 1 egység $1 \mathrm{~kg}$ ) kellett beadni. A beszolgáltatandó mennyiség 1/5-ét gabonában, 1/5-ét zsírban, 3/5-ét szabadon megválasztható terményekben, ill. termékekben kellett teljesíteni. (Pl. $1 \mathrm{q}$ olvasztott zsír 1200, 1 q repce 220, 1 q burgonya 33, $1 \mathrm{~kg}$ tojás 8 búzaegységet jelentett.) A beszolgáltatott terményekért maximált hatósági árat fizettek. Forrás: https://www.arcanum.hu/hu/onlinekiadvanyok/Lexikonok-magyarorszag-a-masodik-vilaghaboruban-lexikon-a-zs-F062E/i-j-F0A5C/jurcsekterv-F0A96/ (Utolsó letöltés: 2019.01.21)

${ }^{163}$ Így pl. kenyérgabonából 3 hónapra 45 kg-ot lehetett megtartani a rendszeresen mezőgazdasági munkát végzők, míg 30 kg-ot azok számára, akik nem végeztek rendszeresen mezőgazdasági munkát. A sommások (időszaki munkások részére) a háromhavi adag max. 150 kg kenyérgabona volt, tekintet nélkül a családtagjaik számára. Aki nem gazdálkodással foglalkozott, de rendelkezett kenyérgabonával vagy liszttel, az ugyancsak 3 hónapot tekintve $32 \mathrm{~kg}$-ot tarthatott meg. Burgonyából a megtartható mennyiség 25 kg/fö/3 hó, hüvelyesekből 6 kg/fó/3 hó volt Forrás: 1945. évi 11.850. K.M. sz. rendelet, Rendeletek Tára 1945., 392. o.

${ }^{164}$ Ráadásul, ha a gazdálkodónak a rendeletben meghatározott terményekből betakarítatlan, illetőleg elcsépeletlen készletei is voltak, akkor a saját maga számára megtartható mennyiségeket - a vetőmag kivételével - elsősorban a be nem takarított, illetőleg el nem csépelt készletből kellett megtartania, a beszolgáltatást pedig a betakarított, elcsépelt készletből kell teljesítenie. A fejadag-határ feletti mennyiségre, vámőrlési engedélyt sem adtak ki.

165 A beszolgáltatási rendszer az 1956-os forradalomig tartotta fenn magát, október 30-án Nagy Imre jelentette be a megszüntetését, ám az erre vonatkozó 1956. évi 21. törvényerejü rendelet a mezögazdasági termények és termékek kötelezö beadásának megszüntetéséröl, már a Kádár-kormány hirdette ki.

166 4300/1945. ME sz. rendelet

${ }^{167} \mathrm{Az}$ adó mértékét 1946. január 1-jétől 4 kg-ra emelték.

168 Nagy-kormány minisztertanácsi jegyzőkönyvei, február 15. Az elfogadott rendeletet - 1680/1946. M.E. sz. rendelet - 1946. február 20-án hirdették ki. 
Az állami törekvések ellenére - új adónemek bevezetése, adózásra buzdító széleskörű sajtópropaganda, stb... - az adóbefizetések az elvártak alatt maradtak - 1946 első négy hónapjában is még csak az állami kiadásoknak mintegy $14 \%$-át sikerült a pénzben beszedett bevételekből fedezni. Gerő Ernő 1945. november 21-i beszámolója szerint: „Az adók késedelmes kivetése és a már kivetett adók késedelmes befizetése folytán a törvényhatóságok közúti alapjai nem rendelkeznek a legszükségesebb kiadások fedezésére szükséges összeggel sem. Nem csak a személyi járandóságokat, a hídroncs kiemelési és újjáépitési munkák költségeit, de a legszükségesebb útfenntartási munkák költségeit sem tudják fedezni."169

Gerő megállapításával szemben fontos hangsúlyozni, hogy a társadalom adószolgáltatás címén - a pénzben kiszabottnál lényegesen nagyobb terhet viselt. Az adóbevételek jelentős részét ugyanis az állam természetbeni adóztatás útján biztosította a maga számára: pl. földadó címén 17.000 vagon adógabonát gyüjtöttek be, amelyet teljes egészében a Közellátási Minisztérium használhatott fel. Ezen felül természetben jelentkezett a textilipar és bőripar termelésének lefölözése, ezen a címen ugyancsak tekintélyes reálérték birtokába jutott az állam. A természetbeni adóbevételek azonban költségvetésen kívül jelentkeztek, és ugyancsak költségvetésen kívül történt az így szerzett árumennyiségek felhasználása közellátási és egyéb (pl. szociális) célokra. Az év első három hónapjában a kimutatott - pénzbeli - bevételek havi három és fél millió békepengőt tettek ki. A természetbeni adóztatás (adógabona, rekvirálás, ipari lefölözés) útján viszont 15 millió békepengőnyi termék folyt be. ${ }^{170}$

Mindezek ellenére a kommunista párt részértől megfogalmazásra került, hogy az adóztatás - elsősorban a forgalmi adók - terén drasztikus elriasztó büntetésre lesz szükség, amely „felrázza az emberek szinte elképesztő adófizetési tunyaságát és az állam szükségletével szembeni érzéketlenségét." ${ }^{171} \mathrm{~A}$,végsőkig züllött adómorál" problémája a Gazdasági Főtanács figyelmét sem kerülte el: 1945. december 11-én tartott ülésükön egy visszamenő hatályú rendelet kiadását határozták el, amely az elkövetett adócsalások, árurejtegetések, árdrágítások vonatkozásában statáriális eljárást léptet életbe, lehetővé téve, hogy az adócsalókat internálják, vagyonukat elkobozzák, iparengedélyüket visszavonják, üzleteiket vagy üzemeiket lefoglalják. Ezáltal „morálra nem is, de móresre meg lehet és meg is kell tanitani öket”. ${ }^{172}$ Különösen a forgalmiadó befizetésének elmulasztását kívánták megtorolni, azon az elven, hogy azt a kereskedők és iparosok nem maguk fizetik, hanem a vevőiktől és megrendelőiktől beszedve, csak továbbítaniuk kell az adópénztárakba, $\mathrm{s}$ ha ezt elmulasztják, tulajdonképpen sikkasztást követnek el. Az adócsalás kérdését ideológiai mázzal vonták be, hogy kiiktathassák a „politikai reakció, a fasiszta érzelmü közigazgatási tisztviselök, ellenforradalmi katonatisztek, nyilas bujtogatók eme leghüségesebb segédcsapatait, melyek most gazdasági téren szállítják politikai cinkosaiknak az annakidején hiába várt csodafegyvereket... Itt az ideje, söt utolsó perce, hogy kényszermunkával, börtönnel, s ha másként nem megy, akasztófával figyelmeztessék őket..." 173

1946-ban az adóterhek tovább nőttek: júliusban került bevezetésre az illetményadó, amelyet a Magyarország területén végzett „szolgálati jogviszonyon” alapuló tevékenységért kapott illetmény után kellett fizetni. Az adó a munkáltatót

\footnotetext{
${ }^{169}$ Tildy-kormány minisztertanácsi jegyzőkönyve 70. sz., 1945. november 21. G. VASS i. m. 2005.

${ }^{170}$ Antos István államtitkár hozzászólása a rendkívüli minisztertanácsi értekezleten, 1946. április 30-án.

${ }^{171}$ Gordon Ferenc elöterjesztése az 1945. december 5-én tartott minisztertanácsi ülésen. G. VASS i. m. 2005. p. 213.

172 Szabadság, I. évf. 269. sz., 1945. december 13

${ }^{173}$ Uo.
} 
terhelte, és összege az illetmény $10 \%$-ában lett meghatározva. ${ }^{174}$ Az illetményadóval egyidőben bevezetésre került egy önmagában is büntető jelleget magán hordozó adónem, az illetmény többletadó. ${ }^{175}$ Ugyancsak 1946 nyarán került bevezetésre a társulati és tantiemadó, ${ }^{176}$ a vagyon többletadó, valamint az együttes kereseti és jövedelemadó, amelyet az ipari és kereskedelmi üzletet vagy szellemi foglalkozást folytatóknak kellett fizetniük. ${ }^{177} \mathrm{Ez}$ utóbbi esetében az adó megállapítása többféle módon történhetett: bevétel alapján, állandó adótételek alkalmazásával, átalányozással, adóközösségi rendszerben vagy un. osztálybasorozással (ez a lehetőség az iparosokra, kereskedőkre és a szellemi foglalkozást folytatókra vonatkozhatott). ${ }^{178}$

1947 januárjában került kihirdetésre a termelői, az általános és a fényüzési forgalmi adóról szóló rendelet, ${ }^{179}$ amellyel a termék előállítását, a szállítását és a szolgáltatásnyújtást adóztatták, meglehetősen széles spektrumon mozgó adókulcsokkal. $\mathrm{Az}$ általános forgalmiadó-kulcs belföldi forgalomban az adóalap 3\% -a volt. Ha azonban bármilyen mennyiségü állati selymet tartalmazó textilipari termékről volt szó, akkor az adókulcs 30\%-os, szücsáruk esetében 20\%-os volt. Aki lakkbőrrel foglalkozott, 40\%-kal adózott, míg az üvegmozaik, vagy a színezett, díszített táblaüvegek adókulcsa 50\%-os volt. Fényüzési forgalmi adó alá estek a nemesfémböl vagy drága- és féldrágakövekből készült ékszerek éppúgy, mint a fényképezőgépek, a hangszerek, valamint a házi kedvencek (kutya, macska, mókus, majom, madár, díszhal, stb) kereskedelmi forgalmazása, a fizetendő adó kulcsa $50 \%$ volt.

A fenti rendelet „fényüzési vállalatként” definiált és 30\%-os adókulcsú fényüzési forgalmi adóval adóztatott egyes tánc- vagy müsorengedéllyel rendelkező vendéglátó üzemet. (Míg az ugyancsak fényüzési forgalmi adót fizető mozik esetében az adókulcs 20 százalék volt.) Azt, hogy melyik szórakozóhely tartozik ide és melyik nem, az illetékes pénzügyigazgatóság és a rendörség döntötte el, s ennek tényét minősítő határozatban közölte. Ezen határozatban megjelölt helyiségekben, minden bevétel után, amelyet a tánc vagy a müsor tartama alatt értek el - beleértve a

\footnotetext{
${ }^{174} \mathrm{Az}$ adófizetés alól mentesítették a közszolgálati illetményeket (pl. az államfőt vagy a nemzetgyülés tagjait a megillető járandóságokat), továbbá az állami üzemek és a társadalombiztosítási intézmények munkavállalóinak Forrás: 8.720/1946. M. E. sz. rendelet az illetményadóról. Magyar Közlöny, 1946.07.31./172/b

${ }^{175}$ Ezt annak a munkavállalónak kellett megfizetnie, aki csak egy munkáltatóval állt szolgálati jogviszonyban és kollektív szerződés hatálya alá nem tartozó illetményének havi összege meghaladta a kollektív szerződés szerint járó legmagasabb szolgálati illetmény havi összegét vagy akinek több munkáltatótól élvezett havi illetményei együttesen meghaladták a kollektív szerződés szerint járó legmagasabb szolgálati illetmény havi összegét. Forrás: 8.7513/1846. M. E. sz. rendelet az illetmény többletadóról. Magyar Közlöny, 1946.07.31. / 172/b. szám

176 osztalékadó.

${ }^{177} 137.000 / 1948$. VII. P. M. számú rendelete az együttes kereseti és jövedelemadóról, a társulati és tantiemadóról, valamint a vagyon többletadóról szóló 5.890/1946. M. E. számú, illetőleg az ennek módosítása és kiegészítése tárgyában kiadott 8.830/1946. M. E. számú rendelet végrehajtásáról. 1946.08.11 / 182. szám

${ }^{178} \mathrm{Az}$ adóalanyok osztálybasorozását az állami adóhivatal székhelyén alakított adókivető bizottság végezte, amely elnökből, valamint négy rendes és négy póttagból állt. A bizottság elnöke (elnökhelyettese) annak az állami adóhivatalnak volt a vezetője, amelynek székhelyén az adókivető bizottság működött. Az adóhivatal területén adózó adóalanyok közül egy-egy rendes és egy-egy póttagot nevezett ki a pénzügyigazgató, a Szakszervezeti Tanács, kettőt-kettőt pedig a kereskedelmi és iparkamarai székhelyeken levő városokban a kereskedelmi és iparkamara két osztálya.

${ }^{179} 100 / 1947$. P. M. sz. rendelet a belföldi forgalomban fizetendő termelői forgalmi adóról, továbbá általános és fényűzési forgalmi adóról. Magyar Közlöny, 1947.01.05. / 4. szám
} 
belépőjegyekből, ruhatári, kuvert- ${ }^{180}$ vagy bármely más címen felszámított díjakból származó bevételeket is -a fényüzési forgalmi adót kellett megfizetniük, és a felszolgált ételek és italok beszerzése alkalmával felszámított általános forgalmi adó beszámításának sem volt helye.

A rendőrség a fényűzési vállalattá minősített vendéglátó helyeknek új tánc- vagy müsorengedélyt csak akkor adott ki, ha a kérelmező az illetékes forgalmi adóhivatal, (Budapesten az illetékes kerületi forgalmi adóosztály) által kiadott bizonyítvánnyal igazolta, hogy adóhátraléka nincs, vagy részletfizetés esetén azt pontosan törleszti. Egyéb esetben az engedélyt nem újították meg, vagy azt visszavonták.

\section{A stabilizáció időszakának adópolitikája}

Az inflációs folyamatot az 1946. augusztus 1-jén bevezetett forint zárta le, amelynek fedezetéül az Magyar Nemzeti Bank nyilasok által nyugatra hurcolt huszonnyolc tonna aranytartaléka szolgált, amit az amerikai hadsereg 1946. augusztus 6-án visszaszolgáltatott a magyar államnak. ${ }^{181}$ A stabilizáció egyik elvárt előzményeként indultak meg háború utáni első költségvetés előkészítő munkálatai 1946 májusában, ${ }^{182}$ az új állami költségvetés pedig 1946. augusztus 1-től 1947. július 31-ig terjedő egy évi időtartamra szólt.

A visszaszolgáltatott aranykészlet az új pénz útjára indításának szükséges feltétele volt, de ahhoz nem elegendő, hogy a stabilizációt hosszú távon fenn tartsa. Ehhez egyéb gazdaságpolitikai intézkedések kellettek, amelyek szorosan összefonódtak a hatalmat fokozatosan megszerző kommunista párt politikai elképzeléseivel. Ahogy Révai József az 1947/1948. évi költségvetés vitájában megfogalmazta: „A gazdasági stabilizáció politikai stabilizáció nélkül fából vaskarika." ${ }^{" 183} \mathrm{~A}$ stabilizáció adórendszere főként az egyenes és forgalmi adókra helyezte a hangsúlyt. Az egyenes adókból származó bevételek az 1946 szeptemberi 46,2 millió forintról 1947 júniusára 90,4 millió forintra, a forgalmi adóké az 1946 szeptemberében behajtott 36 millió forintról 1947 júniusára 91 millió forintra emelkedtek. A stabilizációs év első 11 hónapjában az összes 3.258,5 millió forintot kitevő állami költségvetési kiadással 2.991,9 milliós állami bevétel áll szemben. ${ }^{184} \mathrm{Az}$ adóztatás fó célja - az állami bevételek biztosítása mellett továbbra is a társadalom szerkezetének erőszakos megváltoztatása volt.

\footnotetext{
${ }^{180} \mathrm{Az}$ üzletbe lépéskor személyenként megváltott minimális fogyasztási jegy, amelynek értékét a vendég fogyasztásának végösszegéből a számla kifizetésekor levonták.

181 JUHÁsZ István: Vesztesként a II. világháború után: hiperinfláció, új forint.https://ado.hu/ado/veszteskent-a-ii-vilaghaboru-utan-hiperinflacio-uj-forint-3-resz/ Letöltve: 2019.07.08. A kérdésről lásd bővebben: KÁDÁR Gábor-VÁGI Zoltán: Aranyvonat. Osiris, Budapest, 2001.

${ }^{182} \mathrm{Az}$ utolsó háborús évben, 1945-ben nem készült költségvetés, a kormány az államháztartást az 1945. évben viselendő közterhekről és fedezendő kiadásokról szóló 1945. évi X. tc.-ben kapott felhatalmazás alapján vitte. Minthogy az egyre növekvő állami kiadásokat túlnyomórészt bankjegyszaporítással fedezték, ezáltal oly mértéküvé fokozva az inflációt, amely az 1946. évre is lehetetlenné tette az állami költségvetés összeállítását. Ezért az államháztartás vitele az 1946. évben is költségvetési törvény nélkül folyt, illetőleg az 1946. november 14-én kihirdetett, az államháztartásnak az 1946. évi január hó 1. napjától az 1946. évi október hó 31. napjáig terjedő viteléröl szóló 1946. évi XVII. törvény, valamint az 1946:XVII. törvénycikkel az államháztartás vitelére adott felhatalmazás meghosszabbitásáról szóló 1946. évi XXVII. tc. által adott felhatalmazáson alapult. ${ }^{182}$

${ }^{183}$ Közli: MóD Aladár: A költségvetési vita mérlege. In: Társadalmi Szemle II. évfolyam, 4. szám, 1947. p. 261.

${ }^{184}$ Berei 1947. 486. p.
} 


\begin{tabular}{|l|c|}
\hline Közigazgatási bevételek megoszlása 1946 VIII. 1-31-ig \\
\hline Egyenesadók & $24,44 \%$ \\
\hline Forgalmiadók & $23,13 \%$ \\
\hline Illetékek & $3,61 \%$ \\
\hline Fogyasztási adók & $5,31 \%$ \\
\hline Cukoradó & $2,98 \%$ \\
\hline Szeszegyedáruság & $6,78 \%$ \\
\hline Vámjövedék & $0,20 \%$ \\
\hline Dohányjövedék & $18,18 \%$ \\
\hline Sójövedék & $1,21 \%$ \\
\hline Sacharin & $0,01 \%$ \\
\hline Újjáépítési sorsjáték & $0,03 \%$ \\
\hline Tárcabevételek & $14,12 \%$ \\
\hline Összesen: & $\mathbf{1 0 0} \%$ \\
\hline
\end{tabular}

Forrás: Zelovich László: Az 1946. évi magyar stabilizáció. In: Társadalmi Szemle I. évfolyam 10. szám, 1946. 709. $p$.

\section{Az államháztartás bevételeinek és kiadásának alakulása}

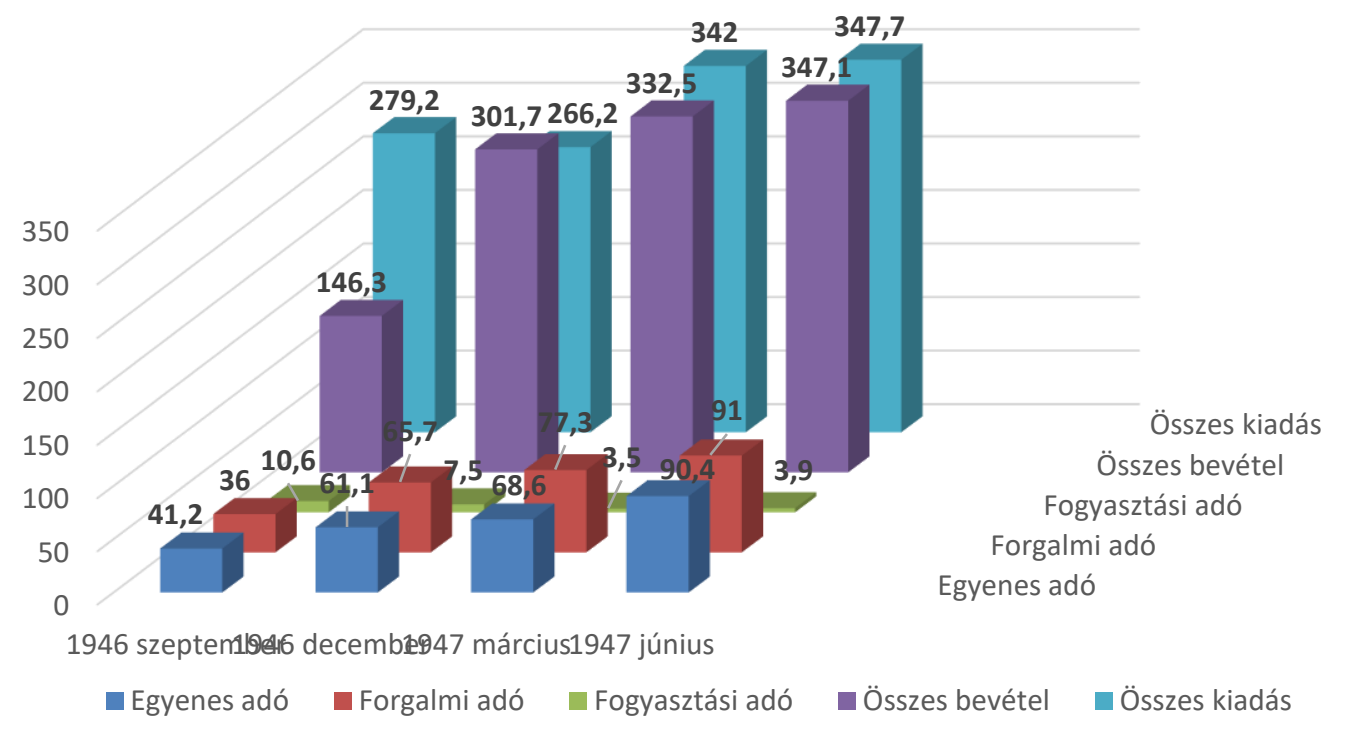

Forrás: a szerzö saját szerkesztése $e^{185}$

A rendszer nem mindenkivel szemben volt szigorú, sőt, az ,adókedvezmény” fogalmát is ismerte - bár azt az állampolgárok vonatkozásában kevéssé érvényesítette -, és alkalmazta is; így pl. az 1945. december 28-án megjelent 12 270/1945. M.E. sz. rendeletet a Magyar-Szovjet Külforgalmi Rt. ${ }^{186}$ részére, öt évre ${ }^{187}$ biztosított adó- és illetékkedvezményeket, ${ }^{188}$ de az összes többi, újonnan alakuló magyar-szovjet vegyesvállalat - mint például a MESZHART, ${ }^{189}$ a MASZOVLET ${ }^{190}$ - is

185 Adatok forrása: Berei 1947. 486. p.

186 1945. szeptember 20-án, minisztertanácsi határozattal alapított gazdasági társaság, amely 75-25 százalékos arányban a magyar állam és a Magyar Nemzeti Bank tulajdonában állt, és kizárólagos joga volt a Szovjetunióba vagy onnan irányuló kiskereskedelmi áruszállítások lebonyolítására.

${ }^{187}$ A rendelet tervezete szerint a kedvezmények egy évre szóltak volna, de az időbeli hatály a rendeletben már öt év volt.

188 Tildy-kormány minisztertanácsi jegyzőkönyvei, 74. sz., 1945. december 10.

${ }^{189}$ Magyar-Szovjet Hajózási Részvénytársaság: 50-50 százalékos szovjet-magyar tulajdonban álló, szovjet irányítással müködő társaság, amely a Dunán és mellékfolyóin történő folyami hajózás, balatoni folyami, 
adómentességet élveztek. Ugyanígy társulati adó- és illetékkedvezményt kaptak a házszövetkezetek és a (ház)részvénytársaságok tulajdonában lévő épületek, társasházakká való alakításuk során. ${ }^{191}$

\section{Adópolitika a hároméves terv időszakában}

A központosított gazdaságpolitikára épülő stabilizációs program az ország talpra állítását az 1947. augusztus 1-jén - napra pontosan egy évvel a forint bevezetése után indult hároméves terv útján tartotta megvalósíthatónak. Az amúgy két év és öt hónap alatt végrehajtott hároméves terv sikere is a beruházások végrehajtásától függött. A fejlesztés homlokterében a maximálisan feszített ütemü iparosítás állott, a nehézipar azon belül is a bányászat és a kohászat - elsődlegessége jegyében, a mezőgazdaság rovására, annak ellenére, hogy ehhez az országnak sem nyersanyaga, sem forrásai, sem tartalékai nem voltak. Azonban az első tervidőszak a politikában bekövetkező radikális változással is egybeesett, amely a kommunisták számára lehetővé tette a gazdaság (és a társadalom) immár nyílt, szovjet típusú átszervezését. A korszakot az államosítás, a kollektivizálás, a tulajdonosi szerkezet teljes megváltozása jellemezte, amelyhez a jog közjogi szabályozói, közigazgatási és büntetőjogi eszközeit egyaránt igénybe vették.

A hároméves terv egyik legfőbb kérdése tehát a beruházási program, s az ennek következtében felmerülő tőke- és forgótőke-szükséglet volt, hiszen a növekvő termelés és az új létesítmények üzemben tartása megnövekedett személyi és dologi kiadások teljesítését igényelte. ${ }^{192} \mathrm{Az}$,indító tőke” előteremtése érdekében pedig a hatalom továbbra is a társadalom belső tartalékaihoz, vagyis az emberek múltban keletkezett és a jövőben keletkező megtakarításaihoz nyúlt. Ez egyrészt a kiadások visszaszorítását jelentette, amit többek között a fogyasztás felülről irányított korlátozásával és a

továbbá tengeri fuvarozás, folyami kikötők, kikötőhelyek, berendezések és felszerelések kihasználása, folyami és tengeri közlekedés szervezése, szállítmányozási és kereskedelmi bizományi mủveletek elvégzése, hajóépítő és hajójavító gyárak, mühelyek, valamint üzemanyag termelő és beszerző vállalatok üzemben tartása céljából jött létre. 4730/1946. M.E. sz. rendelet (amelynek melléklete a társaság alapszabályát is tartalmazta). Magyar Közlöny, 1946/100. szám, május 4.

190 Magyar-Szovjet Polgári Légiforgalmi Társaság, amelynek alapszabályait - Magyarország és a Szovjetunió közötti gazdasági együttmüködésről szóló, 1945. augusztus 27-én Moszkvában aláírt egyezmény alapján - a 4740/1946. M.E. sz. rendeletben tették közzé. A társaságot magyar részről a Közlekedésügyi Minisztérium, a szovjet oldalról pedig a Népbiztosok Tanácsa mellett müködő Légiforgalmi Főigazgatóság képviselte, az alapító okiratot ennek megfelelősen Gerő Ernő közlekedésügyi miniszter és Berezin Pavel Fedorovics repülő vezérőrnagy írták alá. A társaságba bevitt magyar apport repülöterek, berendezések, földterületek, épületek - jóval nagyobb értéket képviseltek a szovjet fél természetbeni befektetésénél, ami főként a repülőgépmotor-parkból és rádióeszközökből állt. A magyar kormány számára ezen felül elöírták, hogy a társaság alapításával kapcsolatban nem szedhet semmiféle adót vagy illetéket, és biztosítja a társaság benzin és kenőanyag szükségletét. A társaság irányítását a szovjet részről kijelölt vezérigazgató és annak magyar helyettese látta el. A Vezérigazgató - azon túl, hogy mindenügyben kizárólagos döntési joga volt - rendelkezett a Társaság vagyontárgyaival és eszközeivel. Magyar Közlöny, 1946/100. szám, május 4.

${ }^{191}$ A Magyar Közlöny 14. számában 1946. január 17-én közzétett 12 110/1945. M.E. sz. rendeletet. Ebben az esetben a házszövetkezetek és részvénytársaságok úgy alakultak át (szüntek meg), hogy a törzsvagyonukban - tulajdonukban -lévő ingatlanokat átalakították társasházzá, amiben a szövetkezeti tagok vagy részvényesek a részvényeik, üzletrészeik fejében öröklakást kaptak. A vagyonból átengedett vagyonrész (a lakások) után adó- és illetékfizetési kötelezettség állt fenn. A kedvezmény pedig arra vonatkozott, hogy az adót és az illetéket nem a tényleges (pl. inflációt is figyelembe vevő) forgalmi érték alapján állapították meg, hanem a mérlegben feltüntetett érték szerint, ami a fogalmi értéknél jóval kisebb összeg volt.

192 Antos 1947. 93. p. 
közigazgatás nagyarányú létszámleépítésével értek el. Másrészt - minthogy az addig alkalmazott adó- és jövedéki hozamoktól a beruházási program megindításához és fenntartásához elengedhetetlenül szükséges extra bevételeket nem várhattak - új adónemek bevezetésével olyan rendkívüli bevételi forrásokról is gondoskodtak, amelyekkel a meghatározott („tehetős”) társadalmi rétegeket sújtották. ${ }^{193}$ Új adónemként a forgalmiadók között megjelent a rizsforgalmi adó, a jövedékek között az italmérési jövedék és a jelképes összegben (1000 forint) előirányzott jövedéki mélykutatás, ${ }^{194}$ míg az egyenesadók között bevezetésre került a vagyonadó, jövedelemtöbbletadó, a gépjármủadó, a vagyondézsma. ${ }^{195}$ és vagyonszaporulati dézsma. ${ }^{196}$

A vagyondézsma elöírt összege a terv végrehajtása során egyes források szerint összesen 1620 millió forint, ${ }^{197}$ más forrás szerint 1740 millió forintra ${ }^{198}$ rúgott. A hivatalos álláspont szerint ,az adódézsmarendelet gyors és energikus végrehajtása a 3 éves terv megvalósitásának egyik alapvetö feltétele” volt. A vagyonosokat terhelö rendkívüli adó bevezetésétől már a terv első évében (1947-48) 480 millió forint, ${ }^{199}$ az újonnan (vagy újra) bevezetett adóktól összesen 593 millió forint bevételt vártak, ${ }^{200}$ amely összeg elegendő alapul szolgálhat a szükséges indítótőke előteremtéséhez.

\section{Az új adónemekből származó tervezett bevételek 1947/1948-ban (millió forintban)}

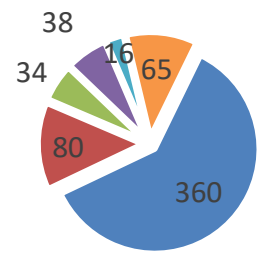

$$
\begin{aligned}
& \text { - Vagyondézsma - Vagyonadó Jövedelemtöbbletadó } \\
& \text { - Illetménytöbbletadó - Gépjármúadó - Fényúzési forgalmi adó }
\end{aligned}
$$

Forrás: a szerző saját szerkesztése $e^{201}$

193 uo 96. p.

${ }^{194}$ A jövedéki mélykutatás a Pénzügyminisztérium tevékenységi körébe tartozóan, 1946-ban indult meg, ahol a Tasnády László miniszteri tanácsos vezette XIII/c. osztály foglalkozott ezekkel az ügyekkel. Az ügyosztály az 1947/48. évi kutató tevékenységét az 1948. évi április 18-án jóváhagyott munkaterv alapján látta el. A terv alapelveit és a kutatások mértékét a Jövedéki Mélykutatási Tanácsadó Bizottság 1947. évi április hó 11-én megtartott ülésén határozta meg. 1948-ban a Gazdasági Főtanács döntése alapján az osztályt kiszervezték a Pénzügyminisztérium irányítása alól, hatáskörét az Iparügyi Minisztérium 1948 november 1-től az Iparügyi Minisztérium bányászati és bányakutatási osztálya vette át. Forrás: Bendefy 1948. pp. 3-4.

${ }^{195}$ Az 1946/1947. évi költségvetés pl.: a vagyondézsma évi összegét 350 millió forintra, a luxusadó összegét 60 millió forintra irányozta elő. Forrás: Szita 1947. 881.p.

196 A magyar állam költségvetése az 1947/1948. évre. Sommázat. Forrás: https://library.hungaricana.hu/hu/view/AllamiKoltsegvetes_1947-1948/?pg=0\&layout=s 44. p. (Letöltve: 2019.07.02.)

${ }^{197}$ ANTOS István: A hároméves gazdasági terv pénzügyi problémái. In: Társadalmi Szemle II. évfolyam, 2. szám, 1947. p. 98.

${ }^{198}$ BEREI Andor: A stabilizáció és a hároméves terv perspektívái. In: Társadalmi Szemle II. évfolyam, 2. szám, 1947. p. 491.

${ }^{199}$ ANTOS i. m. 1947. p. 96.

${ }^{200}$ ANTOS István: Az új költségvetés. In: Társadalmi Szemle III. évfolyam, 2. szám, 1948. p. 107.

${ }^{201}$ Adatok forrása: UO. p. 107. 
A számítások szerint 1947-48-ban a költségvetés „normális” állami bevételei (adók, illetékek, jövedékek) 3.490 millió forintot tettek ki, ami a költségvetési kiadások 83,7 \%-át fedezte. Ez az összeg 1948-49-ben - tervezetten - 4.040 millió Ft (a költségvetési kiadások 81,8 \%-a), 1949-50-ben pedig 4.620 millió forint (a költségvetési kiadások 80,0 \%-a) volt. A hiányt a hároméves terv első évében kizárólag a rendkívüli vagyonadóból akarták pótolni, a terv második és harmadik évében már az üzemekben termelt „felesleg” értékesítéséből, valamint egyéb hitelműveletekből származó bevétellel is terveztek. Ez utóbbi érdekében tervkölcsön-kötvényeket bocsájtottak ki. ${ }^{202}$

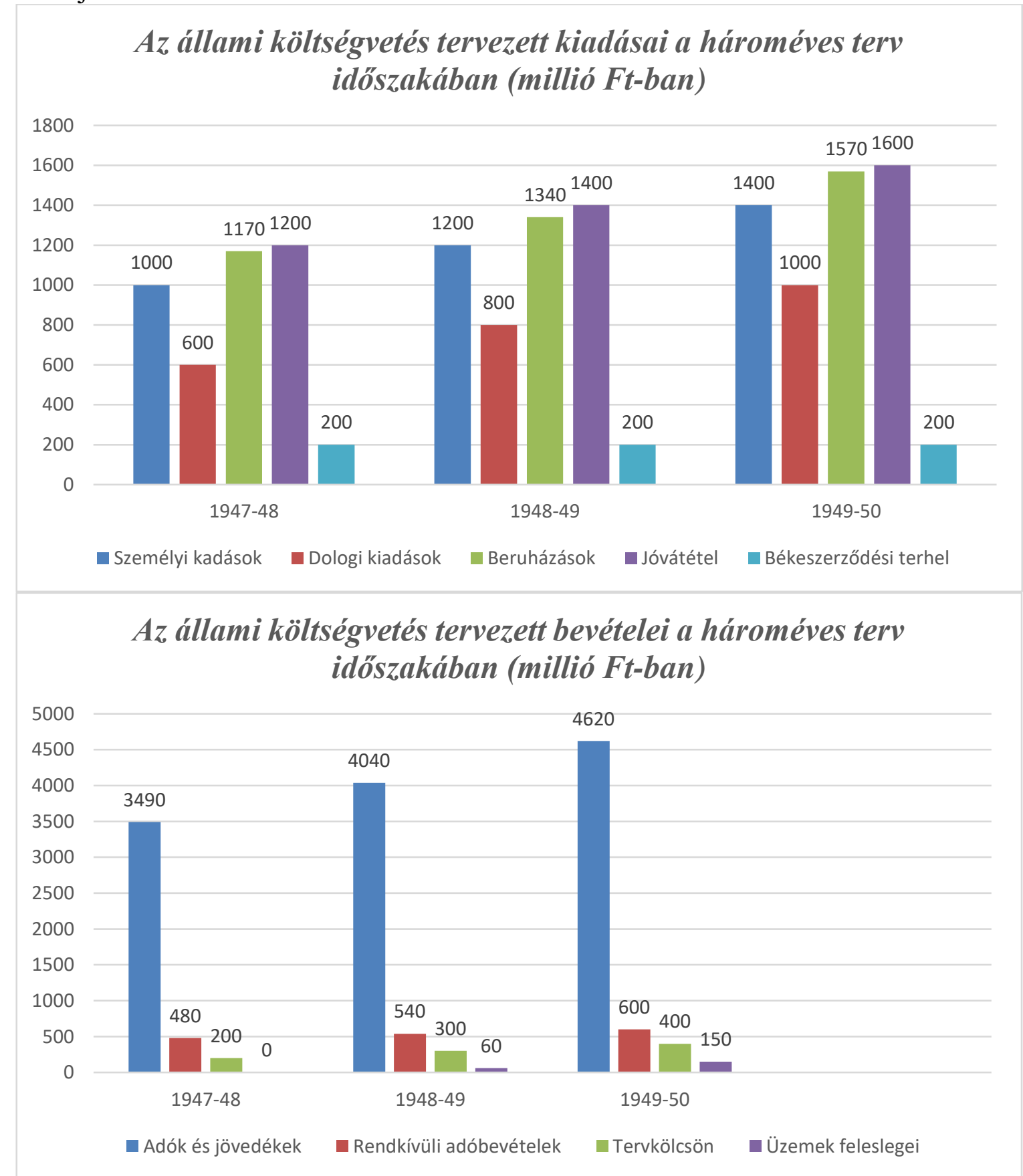

Forrás: a szerzö saját szerkesztése203

${ }^{202}$ ANTOS i. m. 1947. p. 97.

203 Adatok forrása: UO. p. 98. 


\section{5. Összegzés}

Az 1945-1949 közötti időszak adópolitikájáról összességében elmondható, a szovjetek által diktált, és az MKP által képviselt adópolitika alapvetően a tulajdonviszonyok megváltoztatásának, a társadalmi szerkezet átalakításának célját szolgálta, annak eszközévé vált, és egyáltalán nem számolt azokkal a veszteségekkel, amelyek a háború következtében a lakosságot érték.. ${ }^{204}$ Antos István ${ }^{205}$ megfogalmazása szerint: „Ha az állam - adópolitikai eszközökkel - korlátozza egyes, jól kereső rétegek fogyasztását, a másik oldalon - amikor ezeket az összegeket hasznos beruházásokra, szociális és kulturális célokra fordítja -, visszaadja a társadalom alacsony jövedelmü tagjainak azt, amit elöbb igénybe vett..." ${ }^{206}$ Ugyanezen kérdéssel kapcsolatban Mód Aladár ${ }^{207} 1947$-ben még határozottabban fogalmazott: „, Mi örömmel látjuk a forgalmi adóból, az illetékböl és fogyasztási adóból származó jövedelmek emelkedését is, mert ezek a forgalom és a fogyasztás emelkedésére mutatnak, de a demokráciának az eddiginél sokkal határozottabban kell szükségleteit a vagyonos rétegek és a nagyjövedelmüek megadóztatásából fedeznie. Vannak, akik azt kérdik, hol van ma ez a vagyonos és nagyjövedelmü réteg, melyet erösebben lehetne megadóztatni. Nem kell pénzügyi szakértönek lenni ahhoz, hogy ezeket a nagyjövedelmeket és vagyonokat meglássuk. A munkásság és a dolgozó parasztság jól látja a verejtékéböl születö gazdagságot és mindennél inkább elvárja, hogy a demokrácia példát mutasson arra, hogy fordult a világ kereke, a demokrácia nemcsak a dolgozóktól követel áldozatot, hanem megköveteli azt a vagyonos rétegektöl is. Ha ezek a rétegek annakidején tudták finanszírozni a györi programot, a pusztulás, a nemzet rontás programját, úgy a demokráciának meg kell, hogy legyen az ereje, hogy most finanszíroztassa velük a demokratikus újjáépités, a nemzeti újjászületés programját is. "208

\section{Felhasznált irodalom}

[1] AnTos István: A hároméves gazdasági terv pénzügyi problémái. In: Társadalmi Szemle II. évfolyam, 2. szám, 1947.

[2] ANTOS István: Az új költségvetés. In: Társadalmi Szemle III. évfolyam, 2. szám, 1948.

[3] BARÁTH Magdolna: A Kreml árnyékában. Tanulmányok Magyarország és a Szovjetunió kapcsolatainak történetéhez, 1944-1990. Budapest, Gondolat Kiadó, 2014.

[4] BARnA Attila - HorvÁth Attila - MÁTHÉ Gábor - Tóth Zoltán József: Magyar Állam- és jogtörténet. Budapest, Nemzeti Közszolgálati Egyetem, 2014. forrás: http://m.ludita.uni-

nke.hu/repozitorium/bitstream/handle/11410/9983/Teljes\%20sz\%C3\%B6veg!?s equence=1\&isAllowed=y (Letöltve: 2019. 01.22.)

\footnotetext{
${ }^{204}$ BERE i. m. 1947. p. 98.

${ }^{205}$ Antos István (1908-1960) közgazdász, egyetemi tanár (1954-től). 1945. november 23.-tól 1951. január 27-ig a Pénzügyminisztérium politikai államtitkára (MKP), majd pénzügyminiszter-helyettes, 1957. május 9.-től haláláig pedig pénzügyminiszter volt. Részt vett a stabilizáció előkészítésében, és az első hároméves terv kidolgozásában.

${ }^{206}$ ANTOS i. m. 1947. p. 94.

${ }^{207}$ Mód (Oszkó) Aladár (1908-1973), 1945 után az MKP Gazdasági Bizottságának titkára, az ötvenes években az állampárt propagandaosztályának munkatársa, 1954 és 1961 között a Tudományos Ismeretterjesztő Társulat főtitkára, 1954 és 1973 között az ELTE tanszékvezető tanára.

${ }^{208}$ MóD i. m. 1947. p. 261.
} 
[5] BENDEFY László (szerk.): Jelentés a jövedéki mélykutatás 1947/1948. évi munkálatairól. Magyar Pénzügyminisztérium, Budapest, 1948.

[6] BEREI Andor: A stabilizáció és a hároméves terv perspektivái. In: Társadalmi Szemle II. évfolyam, 2. szám, 1947.

[7] BEREND T. Iván: A gazdaságpolitika fö vonásai Magyarországon (1948-1968). Hosszú távú Tervezés Közgazdasági Bizottsága által megvitatott tanulmány. 2009.04.23.

[8] http://www.makrotrend2000.hu/index.php?id_embed=13. (Letöltve: 2019.01 27.)

[9] Csizmadia Tamás: A hatalomátvétel - Út a kommunista totális állam felé 1944 december 21-töl a jogági szilárdulásig. Doktori értekezés. 2016. https://ajk.pte.hu/files/file/.../csizmadia-tamas/csizmadia-tamas-muhelyvitaertekezes.pdf(Letöltve: 2019.01 29.)

[10] D. PETROVSZKIJ: A népi demokrácia országainak gazdasági föllendülése. In: Magyar-Szovjet Közgazdasági Szemle, III. évfolyam 1-6. szám, 1949. januárjúnius.

[11] DANYI Pál: Hiperinfláció 4. rész: 1946. május végén jelent meg az adópengő mint papírpénz. 2016. Forrás: http://webcache.googleusercontent.com/search?q=cache:VERCa1nUc9MJ:https: //www.artortenet.hu/index.php/item/124-hiperinflacio-4-resz-1946-majusvegen-jelent-meg-az-adopengo-mint-papirpenz\&client=firefoxb\&hl=hu\&gl=hu\&strip=1\&vwsrc=0 (Letöltve: 2018 . december 17.)

[12] G. VASS István:Tildy Zoltán kormányának minisztertanácsi jegyzökönyvei 1945. november 15.-1946. február 4. Magyar Országos Levéltár kiadványai, II. Forráskiadványok 41. Budapest, 2005.

[13] GERMUSKA Pál: Adalékok a magyarországi gazdasági intézményrendszer 1945 1948 közötti változásaihoz. In: Lépések a gazdasági teljhatalom felé 1945-1948. Nemzeti Emlékezet Bizottsága, Budapest, 2017.

[14] GönCZÖL József - LÁBÁN József: A mezögazdasági jövedelemadó új rendszere. In: Közgazdasági Szemle, III. évfolyam, 1956.

[15] GyARMATI György: A Rákosi-korszak. Rendszerváltó fordulatok évtizede Magyarországon, 1945-1956. ÁBTL-Rubicon, Budapest, 2011.

[16] HONVÁRI János (szerk.): Magyarország gazdaságtörténete a honfoglalástól a 20. század közepéig. Aula, Budapest, 1997.

[17] HonvÁRIJános: Magyar jóvátétel a II. világháború után. In: RubicOnline 2012/3. www.rubiconline.hu (Letöltve: 2019.04.17.)

[18] HoRvÁTH Julianna -SzABÓ Éva -SzÜCs László -ZALAI Katalin (szerk.): Pártközi értekezletek... Politikai érdekegyeztetés, politikai konfrontáció 19441948. Budapest, Napvilág Kiadó, 2003.

[19] HuSzTI Ernő: Hetven éves a magyar forint. Pénzügyi Szemle 2016/4.

[20] IzSÁK Lajos: Rendszerváltástól rendszerváltásig. Magyarország története 19441990. Kulturtrade Kiadó, Budapest, 1998.

[21] JuHÁSz István: Vesztesként a II. világháború után: hiperinfláció, új forint. https://ado.hu/ado/veszteskent-a-ii-vilaghaboru-utan-hiperinflacio-uj-forint-3resz/ (Letöltve: 2019.07.08.)

[22] LENTNER Csaba: A magyar állampénzügyek fejlödéstörténete a dualizmus korától napjainkig. L'Harmattan, Budapest, 2019.

[23] MAJOROS Krisztina: A múlt század jeles magyar közgazdásza: Varga István. MTA Közgazdaságtudományi Kutatóközpont, Budapest, 2003. 
http://docplayer.hu/9010881-A-mult-szazad-jeles-magyar-kozgazdasza-vargaistvan-1897-1962.html (Letöltve: 2019.02.16.)

[24] MARTON Ádám: Infláció, fogyasztói árak Magyarországon a II. világháború után (1945-1968). In: Statisztikai Szemle 90. évfolyam, 5. szám, 2012. május. 376. o. http://www.ksh.hu/statszemle_archive/2012/2012_05/2012_05_001.pdf (Letöltve: 2019. 01.23.)

[25] MóD Aladár: Az újjáépités gazdaságpolitikája. In: Társadalmi Szemle I. évfolyam, 1. szám, 1946.

[26] MóD Aladár: A költségvetési vita mérlege. In: Társadalmi Szemle II. évfolyam, 4. szám, 1947.

[27] PETÖ Iván-SzAKÁCs Sándor: A hazai gazdaság négy évtizedének története 1945 1985. I. Az újjáépités és a tervutasitásos irányitás időszaka. Budapest, Közgazdasági és Jogi Könyvkiadó, 1985.

[28] SchletT András: A magyar tanulópénz - Hiperinfláció és stabilizáció Magyarországon1945-46-ban. (kézirat)

[29] SzITA János: A gazdasági helyzet. In: Társadalmi Szemle II. évfolyam, 12. szám, 1947. 881. p.

[30] A magyar állam költségvetése az 1947/1948. évre. Sommázat. Forrás: https://library.hungaricana.hu/hu/view/AllamiKoltsegvetes_19471948/?pg=0\&layout=s (Letöltve: 2019.07.02.)

[31] TOMKA Béla: A magyarországi pénzintézetek rövid története 1936-1947. Budapest, Aula Kiadó, 2000.

[32] V. DJACSENKo: A szovjet pénzügyi rendszer jellegzetességei és elönyei. In: Magyar-Szovjet Közgazdasági Szemle, Magyar-Szovjet Közgazdasági Szemle, III. évfolyam 1-6. szám, 1949. január-június.

[33] VARGA István: Az újabb magyar pénztörténet és egyes elméleti tanulságai. Közgazdasági és Jogi Könyvkiadó, Bp., 1964.

[34] VÁGI József: Pengővalorizáció. In: Jogtudományi Közlöny I. évfolyam/1-2. szám, 1946. január 31.

[35] VÁGÓ József: Infláció - stabilizáció. Magyar Gazdasági Évkönyv 1945-1947. Budapest, 1947.

[36] Szabad Nép, III. évfolyam, 218. szám, 1945. december 18. Forrás: www.arcanum.hu

[37] Szabadság I. évfolyam, 247. sz., 1945. november 16. Forrás: www.arcanum.hu

[38] Szabadság, I. évf. 269. sz., 1945. december 13. Forrás: www.arcanum.hu

[39] Világ, 1945. december 30. (185. szám) Forrás: www.arcanum.hu

[40] https://www.arcanum.hu/hu/online-kiadvanyok/Lexikonok-magyarorszag-amasodik-vilaghaboruban-lexikon-a-Zs-F062E/i-j-F0A5C/jurcsek-terv-F0A96/ (Letöltve: 2019.01.21)

Lektorálta: Bank Barbara Dr. PhD. történész, bizottsági tag Nemzeti Emlékezet Bizottsága

barbi.bank@gmail.com 